DANUTA PiRÓG

Uniwersytet Pedagogiczny, Kraków, Polska

\title{
Konkurowanie uniwersytetów na rynku usług edukacyjnych w warunkach kryzysu gospodarczego i nasilających się trudności tranzycji absolwentów
}

\section{Competition among universities on the educational services market in the circumstances of economics crisis and increased transition difficulties}

\begin{abstract}
Streszczenie: Uczelnie są szczególnym przypadkiem instytucji, w których ważną rolę odgrywają wartości wyższe i misja społeczna. Zmiany zachodzące w otoczeniu uniwersytetów, zwłaszcza urynkowienie i umasowienie szkolnictwa wyższego, globalizacja i internacjonalizacja oraz przemiany na rynku pracy spowodowały, że zaczęły one funkcjonować w przestrzeni silnej konkurencyjności. Skutkowało to m.in. potraktowaniem edukacji akademickiej jako usługi i przyniosło potrzebę nowego podejścia do celów działalności i zarządzania. Jakość usługi edukacyjnej na szczeblu wyższym znacząco wpływa na życie osobiste i zawodowe podmiotów oraz rozwój gospodarczy kraju.

Celem artykułu jest dokonanie analizy najważniejszych strategii konkurowania uczelni na rynku edukacyjnym, szczególnie w aspekcie zapewnienia absolwentom pomyślnego wejścia na rynek pracy i jak najlepszej pozycji na nim. Uwagę skierowano przede wszystkim na instrumenty budowania długoterminowych relacji z szeroko pojętymi odbiorcami usług edukacyjnych i badawczych oraz zarządzania nimi jako kluczowego źródła przewagi konkurencyjnej.
\end{abstract}

Abstract: Universities are the kind of institutions where values, as well as social mission, play an
essential role. A wide range of changes, especially marketisation and massification of the higher educa-
tion system, globalisation, internalisation, turbulence on the labour market, has resulted in universities
existing in an atmosphere of strong competitiveness. It re-evaluated higher education as a kind of
a service. This process also led to a new way of treating higher education aims, and an innovative style
of managing HE institutions became necessary. Moreover, the quality of the HE educational service
significantly influences both the private and professional life of individuals, society and the economic
development in the country.
The aim of the paper is to present an analysis of key strategies and tools of competition among uni-
versities on the labour market, especially in the aspect of providing their graduates with a successful
transition into the labour market. The principal consideration will be devoted to instruments of build- 
ing and managing long-term relations with broadly understood customers as a fundamental source of competitiveness.

Słowa kluczowe: absolwent; długoterminowe relacje; konkurowanie; pracodawca; szkoła wyższa

Keywords: graduate; long-term relations; competition; employer; higher education

\section{WSTĘP}

Po transformacji ustrojowej kształcenie akademickie w Polsce zaczęło odbywać się w warunkach zliberalizowanego systemu edukacyjnego i przy rosnących aspiracjach społeczeństwa, dotyczących posiadania dyplomu ukończenia szkoły wyższej. Duży popyt na studiowanie nie był dla uczelni bodźcem do dodatkowych działań zwiększających konkurencyjność na rynku usług edukacyjnych. Popyt ten generował dynamiczne powstawanie szkół niepaństwowych i zwiększanie limitów przyjęć na studia niemal w każdej instytucji oferującej wyższe wykształcenie. Obserwowany w ostatnich latach niż demograficzny przyniósł narastające obawy wielu uczelni o pozyskanie kandydatów do studiowania (Sztanderska i in., 2005a; Sztanderska i in., 2005b; Jakubowska, Rosa, 2011; Kryńska, 2011). Część z nich wprowadziła przemyślane i zakrojone na szeroką skalę strategie, mające na celu podnoszenie konkurencyjności proponowanej oferty kształcenia. Wiele szkół wyższych ograniczyło swoje działania w tym zakresie do obniżania wymagań stawianych kandydatom i studentom oraz podnoszenia limitów miejsc na poszczególnych kierunkach.

Przemiany społeczne, zwłaszcza wspomniany niż demograficzny i sytuacja na rynku pracy, spowodowały, że konkurowanie między uczelniami już przybrało lub przybierze nowe oblicza. Jednym z zasadniczych kierunków rywalizacji stanie się udowodnienie klientom, zwłaszcza kandydatom do studiowania, że ukończenie studiów na danej uczelni optymalizuje ich sytuację na wymagającym rynku pracy (Teichler, 2011). W niektórych krajach europejskich wskaźniki osiągnięć (performance indicators), konstruowane w oparciu o zatrudnienie absolwentów po ok. sześciu miesiącach od formalnego zakończeniu studiów, są jednym z najistotniejszych komponentów oceny jakości pracy uczelni, warunkującym jej pozycję w większości rankingów (Hemsley-Brown, Oplatka, 2006). Aspekt prawdopodobieństwa pozyskania pracy odpowiadającej poziomowi wykształcenia staje się coraz istotniejszym kryterium wyboru danej uczelni i kierunku kształcenia przez młodzież.

Już w latach 80. XX wieku różne grupy interesariuszy zaczęły wysuwać jednoznaczne oczekiwania wobec uczelni wyższych, aby podjęły one działania w celu podnoszenia poziomu zatrudnialności absolwentów oraz płynnej i satysfakcjonującej (merytorycznie i finansowo) tranzycji osób z wyższym wykształceniem (Fulton, 1984). Termin ,zatrudnialność”, wcześniej zarezerwowany przede wszystkim do analiz popytu i podaży na rynku pracy, zaczął być uwzględniany podczas dyskusji i prób pomiaru efektywności pracy szkoły wyższej (Bielecki, 2011).

Niełatwa sytuacja osób z dyplomem ukończenia wyższej uczelni na rynku pracy zaowocowała wyraźną tendencją do nawiązywania, tak w programach studiów, jak i metodach 
kształcenia, do potrzeb pracodawców i mierzenia efektywności tych działań przez poznanie zawodowej sytuacji absolwentów (Cranmer, 2006; Teichler, 2011). W zapisach Deklaracji Bolońskiej położono duży nacisk na kwestie przyszłości zawodowej absolwentów szkół wyższych. Aby ułatwiać im poszukiwanie zatrudnienia na międzynarodowym rynku pracy, przyjęto system porównywalnych stopni i wprowadzono suplement do dyplomu. Zobowiązano poszczególne kraje do reformowania swoich systemów edukacji akademickiej, m.in. w zakresie podnoszenia szans absolwentów na rynku pracy. Konieczność troski o pomyślne wejście absolwentów na rynek pracy podkreślali także rektorzy wielu uniwersytetów europejskich (Banaszak, 2012).

Starania uczelni o to, aby w zakresie właściwym dla danej instytucji przyczyniać się do tego, aby stworzyć absolwentom optymalne warunki do przejścia ze świata edukacji do pracy zawodowej, powinny objąć szereg długofalowych i przemyślanych działań. Strategie podnoszenia konkurencyjności absolwentów na rynku pracy odnoszą się zarówno do pozyskiwania pracy najemnej, jak i podejmowania samozatrudnienia (Marginson 2004; Marginson, 2006; Romero, del Rey 2004; Hemsley-Brown, Oplatka, 2006; Drapińska, 2011).

Celem artykułu jest dokonanie analizy kluczowych strategii konkurowania uczelni na rynku usług edukacyjnych, przede wszystkim w aspekcie zapewnienia swoim absolwentom pomyślnego wejścia na rynek pracy i jak najlepszej ich pozycji na nim. Skupiono się zwłaszcza na strategiach budowania i elementach zarządzania długoterminowymi relacjami z szeroko pojętymi odbiorcami usług edukacyjnych, ze szczególnym uwzględnieniem pracodawców, studentów i absolwentów.

Do realizacji celu zastosowano metodę studiów literatury krajowej i zagranicznej.

\section{SPECYFIKA KONKUROWANIA UCZELNI WYŻSZYCH}

W okresie gospodarki centralnie sterowanej szkolnictwo wyższe było kontrolowane przez państwo, które finansowało jego wydatki. Nie istniały przesłanki do pozanaukowego konkurowania uczelni między sobą, stąd nie mają one tradycji, doświadczenia, a nieraz też i przekonania o zasadności tego typu działań. Obecnie uniwersytety muszą konkurować ze sobą na wielu płaszczyznach, w tym zwłaszcza o środki finansowe na kształcenie studentów i prowadzenie badań naukowych, o kandydatów do studiowania i o samodzielnych, głównie tytularnych pracowników naukowych. Zdolność do konkurowania to ważny element funkcjonowania uczelni, tak w skali ogólnouniwersyteckiej, jak i dla poszczególnych członków społeczności akademickiej.

Rosnąca potrzeba konkurowania uczelni między sobą rodzi konieczność (do pewnego stopnia) traktowania ich jak przedsiębiorstwa i zarządzania nimi w ten sposób (Romero, del Rey, 2004; Hemsley-Brown, Oplatka 2006; Marginson, 2006). Nadto koncepcja społeczeństwa opartego na wiedzy, sytuująca uczelnie w roli zasadniczego „dostawcy” kapitału ludzkiego, stanowiącego o poziomie rozwoju gospodarczego oraz o społecznym statusie jednostki, skutkowała ewolucją szkół wyższych w stronę „przedsiębiorstwa badawczego” (Siwiński, 2013: 129). 
Nasilające się i współwystępujące procesy globalizacji, autonomii uczelni oraz urynkowienia kształcenia na poziomie wyższym spowodowały konieczność potraktowania edukacji na tym szczeblu w kategoriach usługi. Niezbędna okazała się także świadomość faktu, że studenci jako kluczowi interesariusze są fundamentem dalszego funkcjonowania szkoły wyższej. Spojrzenie na szkolnictwo wyższe jako na miejsce świadczenia usług znalazło wyraz w ustawie o szkolnictwie wyższym z 27 lipca 2005 roku (art. 13 ust. 1 pkt 3), w której do podstawowych zadań uczelni zaliczono ,prowadzenie badań naukowych i prac rozwojowych oraz świadczenie usług badawczych". W warunkach gospodarki rynkowej ważnym elementem budującym jakość tej usługi jest „kształcenie studentów w celu ich przygotowania do pracy zawodowej" (art. 13 ust. 1 pkt 1).

Konkurowanie pomiędzy szkołami wyższymi ma jednak charakter swoisty i zdecydowanie odmienny od rywalizacji przedsiębiorstw i wielu innych instytucji. Zasadniczą tego przyczyną jest specyfika działalności uniwersytetów, wynikająca z faktu, że w ich funkcjonowaniu ważną rolę odgrywają (lub powinny odgrywać) wartości wyższe i misja społeczna. To powoduje, iż niemożliwe jest przyjęcie strategii działań, która odnosiłaby się tylko do płaszczyzny ekonomicznej i miałaby na celu jedynie osiągnięcie jak najwyższych zysków materialnych. W przypadku uczelni wyższych, w odróżnieniu od zdecydowanej większości przedsiębiorstw $\mathrm{i}$ innych instytucji, konkurowanie odbywa się w znacznym stopniu w wymiarze społecznym. Ich pozycja na rynku usług jest zdeterminowana przez czynniki pozaekonomiczne, jak np. reputacja, prestiż i spodziewany przez otoczenie osiągnięty szeroko pojęty status społeczny absolwenta. Dwa pierwsze czynniki stanowią przede wszystkim rezultat zaangażowania i profesjonalizmu pracowników, których działania są głównie konsekwencją ich idealistycznych motywacji. W większości europejskich uniwersytetów status materialny i pozycja nauczyciela akademickiego jest wyłącznie efektem jego pracy naukowej, a nie kunsztu. Wysoki poziom prowadzonych kursów, przesądzający o reputacji uczelni czy kierunku kształcenia, jest zatem rezultatem tych wymiarów działań pracowników, które, wymagając od nich dużego nakładu pracy, nie przekładają się na ich zyski finansowe (Franck, Schönfelder, 2000).

Konkurowanie uczelni między sobą jest potęgowane przez ich wyraźną koncentrację w dużych ośrodkach akademickich (Schüller, Rašticová, 2011) i dynamiczne nasilanie się trudności w pozyskaniu kolejnych kandydatów do studiowania (Doucouliagos, Abbott, 2007). Jednym z dowodów na istnienie coraz intensywniejszej atmosfery konkurencji między uczelniami wyższymi są przygotowywane i z różną intensywnością oddziałujące na proces wyboru studiów przez młodzież rankingi uczelni wyższych. Ich wpływ na stopień zainteresowania studiowaniem na danej uczelni czy kierunku rośnie wraz ze wzrostem ryzyka osiągnięcia ekonomicznych i społecznych profitów, płynących z posiadania wyższego wykształcenia (Marginson, 2004; Marginson, 2006).

Wreszcie specyfiką konkurowania uczelni jest „niemożność bezpośredniej i jednoznacznej weryfikacji ich pozycji konkurencyjnej”, która w świecie biznesu jest wyznaczana przez pozycję rynkową (Siwiński, 2013: 130). W branży usług edukacyjnych, w aktualnych uwarunkowaniach gospodarczych, ważnym wyznacznikiem tej pozycji jest sytuacja absolwentów poszczególnych uczelni na rynku pracy. 


\section{STRATEGIE KONKUROWANIA}

\section{Budowanie relacji}

Podstawą do wypracowania strategii konkurowania szkoły wyższej na rynku usług edukacyjnych jest uświadomienie sobie, że funkcjonuje ona w otoczeniu swoich klientów, zwanych interesariuszami. Są to przede wszystkim: studenci, absolwenci i ich rodzice, pracownicy uczelni, pracodawcy, szkoły średnie, inne uczelnie, społeczność lokalna, akcjonariusze i udziałowcy uczelni, rząd oraz instytucje kontroli (Cichoń, 2010). Zakłada się, że źródeł przewagi konkurencyjnej należy obecnie upatrywać w umiejętności budowania długoterminowych i satysfakcjonujących relacji z partnerami w otoczeniu (Drapińska, 2011; Leja, 2013).

Każda z relacji jest ważna, a holistyczne potraktowanie kreowania i utrzymywania sieci powiązań między otoczeniem a uczelnią zapewnia właściwy klimat do budowania dobrej pozycji i pozytywnej percepcji społecznej absolwentów. Z punktu widzenia procesów tranzycji szczególnie istotne jest umiejętne nawiązanie i utrzymywanie stosunków z pracodawcami. Mobilność studentów i absolwentów na całym świecie jest relatywnie niska i zdecydowana większość z nich będzie dążyła do pozyskania zatrudnienia w pobliżu miejsca ukończenia szkoły wyższej. Zasadne jest dogłębne rozpoznanie lokalnego rynku pracy i wypracowanie trwałych relacji uczelni z tymi pracodawcami. Wachlarz sieci powiązań uczelnia - pracodawcy można uzupełniać też o firmy działające w znacznej odległości od danego ośrodka akademickiego (Franck, Schönfelder, 2000).

W aktualnych uwarunkowaniach rynku pracy pracodawcy dysponują bardzo dużą liczbą kandydatów legitymujących się wyższym wykształceniem i najczęściej wybierają absolwentów tych uczelni, do jakości kapitału edukacyjnego których mają duże zaufanie. Przekonanie, iż dana szkoła wyższa zapewnia podaż wysokiej jakości pracowników, wyposażonych w specjalistyczne i wyróżniające ich kompetencje, można efektywnie kreować poprzez współpracę uczelni z pracodawcami w zakresie projektowania i realizowania wybranych elementów procesu dydaktycznego. Wówczas pracodawcy, mając sposobność do bezpośredniej obserwacji, uczestniczenia oraz kreacji procesu kształcenia, mogą nabrać dogłębnego przekonania o wysokiej jakości nabywanych przez studentów umiejętności. To poskutkuje ich większą gotowością do zatrudnienia absolwentów konkretnej uczelni i kierunku oraz - jak dowodzą badania geografów - powszechnym rekrutowaniem do pracy wybranych studentów jeszcze w toku studiów (Clark i in., 1990).

Narzędziem do diagnozy tej relacji, tj. weryfikacji występowania i jej kondycji, jest audyt programu studiów, a w nim ocena kontaktów z pracodawcami. W ten sposób można sprawdzić m.in., czy potencjalni pracodawcy biorą czynny udział w pracach nad konstruowaniem programów kształcenia akademickiego, czy są zaangażowani w realizowanie obligatoryjnej oferty programowej poprzez prowadzenie wybranych zajęć lub części zajęć, czy prace licencjackie i dyplomowe stanowią odpowiedź na zapotrzebowanie pracodawców, mają znaczenie aplikacyjne i są próbą rozwiązania konkretnych (zamówionych) zadań oraz czy pracodawcy są stałym elementem rzeczywistości akademickiej, np. poprzez prelekcje, 
gościnne wykłady, występowanie w roli ekspertów - praktyków na uczelnianych konferencjach (Piróg, 2011).

Rezultaty audytu, ujawniające charakter dotychczasowych relacji, powinny być przesłanką albo do ich dalszego pielęgnowania na najwyższym poziomie, albo do inicjowania powiązań. W literaturze za skuteczne narzędzie do rozpoczynania, pogłębiania i wzmacniania tych relacji uznaje się najczęściej dwie strategie uczynienia pracodawców realnymi kreatorami i wykonawcami części procesu dydaktycznego. Pierwsza to tzw. sandwich degree studies. Jest to organizacja toku studiów, wypracowana i wdrożona do praktyki edukacyjnej głównie na uczelniach politechnicznych, w której zakłada się, że jeden (najczęściej przedostatni) rok studiów odbywa się w formie ciągłego stażu i praktyki u pracodawcy. Celem tej praktyki jest empiryczne wykorzystanie kompetencji nabytych na studiach kierunkowych oraz wypracowanie pozostałych umiejętności, fundamentalnych w pracy w określonej firmie czy instytucji. Proces ten odbywa się w ścisłej współpracy wszystkich zaangażowanych podmiotów. Pracodawca stawia przed studentem-stażystą konkretne zadania oraz zapewnia mu pomoc techniczną i praktyczną innych pracowników. Student, za każdym razem z większą samodzielnością, realizuje te zadania. Pracownicy uczelni (nauczyciele akademiccy) są merytorycznym wsparciem i ekspertami w całym procesie wykonania danego projektu (Clark i in., 1990; Hennemann, Liefner, 2010).

Drugie, stosunkowo łatwe do wdrożenia w polskiej rzeczywistości szkolnictwa wyższego działanie polega na realizowaniu aplikacyjnych bloków interdyscyplinarnych kursów lub modułów, opartych na zastosowaniu metody projektu (PBL, problem/project-based learning) oraz metod praktycznych (WBL, work-based learning) (Pawson i in., 2006). Udział interesariuszy - pracodawców w realizacji modułu może mieć różny charakter: od zaangażowania ich - z głosem doradczym - w konstruowanie planów, programów studiów, przez zapraszanie do prowadzenia części zajęć dydaktycznych, oceniania efektów kształcenia, do realizowania wspólnych projektów badawczych uczelni i przedsiębiorstw (Kabaj, Jeruszka, 2009). W praktyce szkoły wyższej zakłada się, że w ramach modułu pakiet wiedzy jest zdobywany na wykładach i seminariach, a umiejętności są wstępnie nabywane na ćwiczeniach i doskonalone w działaniu, np. w badaniach terenowych. Kompetencje formalne uzyskuje student w toku praktycznego działania w zespołach, opracowywania i prezentowania wyników na forum instytucji naukowej i z udziałem interesariuszy (Piróg, 2012b).

Podstawowe korzyści takiej współpracy zamieszczono w tab. 1. Z punktu widzenia kluczowej dla procesu tranzycji relacji z pracodawcami ważne jest zbudowanie ich trwałego zaufania do jakości procesu kształcenia w danej szkole wyższej (kierunku) w żywej i partnerskiej więzi z uczelnią. Poziom zaufania do wartości kapitału edukacyjnego absolwentów danej uczelni (kierunku) można w tych relacjach efektywnie budować poprzez współpracę szkoły z pracodawcą w kwestii opracowywania i realizowania wybranych elementów procesu dydaktycznego. Pracodawcy mogą się przekonać, że studenci są wyposażeni w wysokiej jakości specjalistyczne i wyróżniające ich kompetencje. Ponadto mają okazję do ewentualnego przeszkolenia swoich przyszłych pracowników zgodnie z potrzebami ich profilu działalności. Umiejętności te można nabywać, doskonalić lub weryfikować ich poziom w trakcie wykonywania części rzeczywistych projektów. Pracodawca może w ten sposób obniżać 
koszty wykonania zadania, a studentom umożliwia się praktyczne wykorzystanie wiedzy zdobytej na studiach.

Tab.1. Korzyści i zagrożenia (utrudnienia) stosowania projektów w edukacji akademickiej

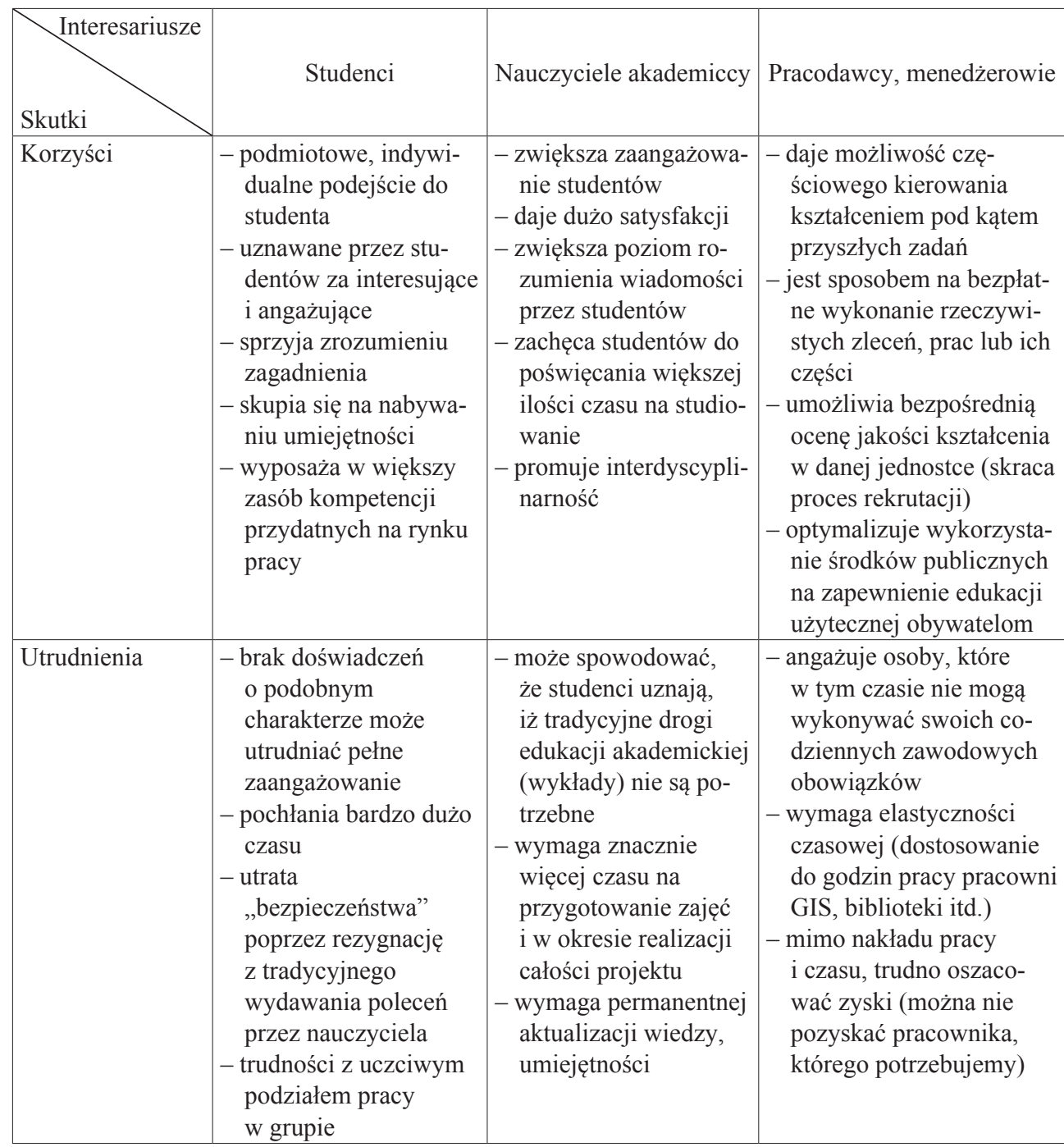

Źródło: opracowanie własne na podstawie Pawson i in., 2006

Kolejną bardzo ważną zbiorowością są potencjalni i realni studenci (krajowi i zagraniczni) oraz absolwenci. Stanowią oni szczególny przykład interesariuszy, bowiem są traktowani zarówno jako klienci - odbiorcy usługi edukacyjnej, jak i jako ,produkt” szkoły wyższej, którego ogólna charakterystyka zawarta jest w opisie sylwetki absolwenta (Doroszewicz, 2011). 
Nawiązywanie relacji z każdą z wymienionych subpopulacji interesariuszy stanowi podstawę pozyskiwania kandydatów do studiowania. Jak wskazują badania, obecnie najefektywniejszym narzędziem stosowanym w tym celu jest strona internetowa danej jednostki. Zawartość strony WWW, a zwłaszcza dostępność na niej, w kilku językach obcych, aktualnych i wyczerpujących informacji o specyfice uczelni, ofercie kształcenia na danych kierunkach, kompetencjach kadry naukowo-dydaktycznej oraz szybka reakcja na pytania kierowane do jednostki i dotyczące warunków podejmowania studiów przez młodzież, stanowi podstawę do pozyskiwania kandydatów. Formy kontaktu z młodzieżą, które także mają znaczenie (choć znacznie mniejsze niż strona internetowa), to dni otwarte na uczelniach oraz nieformalne kanały przepływu informacji, głównie opinie absolwentów. Pozostałe sposoby budowania relacji z ewentualnymi kandydatami, w tym reklamy radiowe oraz prasowe, zostały dostrzeżone zaledwie przez 1,3\% studentów. Rośnie zainteresowanie kontaktami przez media społecznościowe, takie jak Facebook czy Twitter, oraz efektywność ich wykorzystywania (Schüller, Rašticová, 2011).

W warunkach internacjonalizacji kształcenia oraz spadku populacji kandydatów na studia wyższe ważnym elementem działań umożliwiających utrzymanie się i dalsze pomyślne funkcjonowanie szkół wyższych jest zachęcanie studentów z innych krajów do studiowania na danej uczelni oraz wspieranie własnych studentów, aby mogli odbywać część studiów na zagranicznych uniwersytetach. Jest to w większości krajów rozwiniętych nie tylko sposób na ratowanie się przed problemem niewypełnienia limitów przyjęć na dane uczelnie i kierunki studiów, ale i znaczące źródło dochodów (Doucouliagos, Abbott, 2007).

\section{Zarządzanie relacjami}

Do podstawowych elementów zarządzania relacjami w usługach edukacyjnych zaliczane są: satysfakcja, wartość, jakość, komunikacja, zaufanie, zaangażowanie, prestiż i wizerunek (Drapińska, 2011). Fundamentem zbudowanych relacji uczelni z otoczeniem jest zapewnienie wysokiej jakości usługi. Dla studentów i absolwentów będzie ona źródłem do wypracowania kompetencji, sprzyjających pozyskaniu satysfakcjonującej pracy po zakończeniu kształcenia, a dla pracodawców - gwarancją efektywnych pracowników.

Jakość kształcenia można rozpatrywać w dwóch ujęciach, pod kątem wymagań formalnych oraz oczekiwań klientów. W zakresie formalnym wymagania określone zostały w ustawie o szkolnictwie wyższym. Są one systemową przesłanką do zapewniania jak najwyższej jakości kształcenia. Weryfikacją stopnia ich realizacji zajmują się komisje akredytacyjne. Pod kątem wymagań klientów uczelni najważniejsza jest subiektywna ocena różnych aspektów usługi, wykonana przez nabywców usługi, która jest częścią oceny pracy uczelni w postępowaniu akredytacyjnym (Doroszewicz, 2011).

Satysfakcja (pojęcie komplementarne w stosunku do wartości) interesariuszy jest konsekwencją rzeczywistych cech usługi edukacyjnej, czyli przydatności zdobytej wiedzy i umiejętności na kolejnych etapach życia człowieka oraz warunków, w jakich te osiągnięcia zostały wypracowane. Jak dowodzą badania, najważniejszymi czynnikami, warunkującymi wysoką satysfakcję studentów są: umiejętności przekazywania wiedzy przez nauczycieli 
akademickich, rozległe merytoryczne kompetencje wykładowców, dostęp do technologii IT i kształcenie z wykorzystaniem najnowszych oprogramowań w toku poszczególnych kursów (Drapińska, 2011 za Douglas i in., 2006). Po zakończeniu studiów poziom satysfakcji z edukacji zależy najbardziej od statusu absolwentów na rynku pracy (Piróg, 2012a). Satysfakcja pozostaje w ścisłym związku z oczekiwaniami. Ważne jest stałe i długotrwałe monitorowanie oczekiwań interesariuszy. W zarządzaniu oczekiwaniami studentów trzeba dążyć do informowania, uświadamiania, wyjaśniania kwestii związanych z procesem kształcenia w kontekście ich aktualnych i przyszłych potrzeb.

Niezbędna w tym i pozostałych działaniach jest skuteczna komunikacja z wszystkimi interesariuszami. Stanowi ona pierwszy krok do budowania relacji na różnych płaszczyznach, szczególnie w warunkach tak dużej konkurencji (Ivy, 2008). Komunikacja jest podstawą do utrzymywania dobrych relacji między klientami a każdą organizacją. W odniesieniu do szkoły wyższej bardzo ważnymi elementami komunikacji są interakcja i dialog, które budują więzi między uczelnią a otoczeniem. Na rynku usług edukacyjnych mają one bardzo duże znaczenie, bowiem „w sytuacji ryzyka i niepewności, które cechują usługi profesjonalne, największym problemem jest brak informacji” (Drapińska, 2011: 199). Permanentne komunikowanie się uczelni z otoczeniem odbywa na wielu płaszczyznach.

W przypadku studentów w trakcie świadczenia usługi edukacyjnej i po jej zakończeniu komunikacja ta obejmuje kilka obszarów i opiera się zarówno na kontakcie bezpośrednim, jak i pośrednim. W zakresie procesu edukacji np. student powinien mieć pełną wiedzę na temat programu, założonych efektów kształcenia i kryteriów zaliczania kursu. Istotne jest nawiązanie relacji pomiędzy studentem a wykładowcą, identyfikacja osobowa studenta, wykazanie życzliwości, przychylności, troski i otwartości na jego pytania lub problemy. Czyni to środowisko uczelniane przyjaznym, „oswojonym”, tworzy podwaliny pod zbudowanie zaufania i identyfikacji studenta z uczelnią. Bardzo istotnym elementem komunikacji w edukacji jest też składanie i dotrzymywanie obietnic. Dobra, częsta i szczera komunikacja ustna (nieformalna) jest uznawana za najskuteczniejszy sposób kreowania relacji o wysokiej trwałości (Marginson, 2004).

Tak realizowana komunikacja stanowi podstawę zaangażowania w relacjach uczelnia wyższa - otoczenie. Zaangażowanie w tym przypadku powinno obejmować m.in. dążenie do długoterminowych relacji. Ważne jest zintegrowanie interesariuszy ze środowiskiem akademickim nie tylko w wymiarze naukowo-edukacyjnym, ale też społecznym i towarzyskim. Zaangażowanie to powinno ujawniać się w trwałych formach kontaktu, realizowanych w różnej formie. Nadto w przypadku populacji absolwentów dobrze przeprowadzana komunikacja może dać uczelni bogate informacje zwrotne o efektywności dotychczas oferowanego przez nią kształcenia.

Wizerunek jest wytworem elementów realnych i pozarealnych oraz efektem komunikowania społeczeństwu cech opisujących dany obiekt, zjawisko. Z pojęciem wizerunku nieodłącznie wiąże się marka uczelni (kierunku) wynikająca z trwale wysokiego poziomu kształcenia, czołowych pozycji w rankingach, bogatej i ciekawej oferty edukacyjnej, której odzwierciedleniem jest poziom kompetencji absolwentów i ich konkurencyjność na rynku pracy. Efektywna komunikacja między szkołą wyższą a otoczeniem wymaga świadomego 
tworzenia wizerunku, który może intensywnie wpływać na pozyskiwanie nowych i jak najlepszych kandydatów na studia, na korzystną percepcję absolwentów przez potencjalnych pracodawców oraz na poziom zainteresowania społeczeństwa wynikami badań naukowych.

Wyróżnia się pięć komponentów, które budują wizerunek uczelni wyższej (kierunku studiów). Są to:

1. komponent psychologiczny, rozumiany jako poziom identyfikacji studenta z uczelnią, której przejawem jest aktywność w działaniach podejmowanych na rzecz uczelni (kierunku studiów), dobrowolna promocja, komunikowanie z dumą, iż jest się studentem danej uczelni (kierunku), chętne eksponowanie elementów stroju zawierającego logo uczelni;

2. komponent socjologiczny, ujawniający się w poczuciu wspólnoty studentów i absolwentów, swoistym patriotyzmie, włączaniu się do zadań zbiorowych;

3. komponent geograficzno-architektoniczny, dotyczący wyglądu budynku, jego otoczenia, wnętrza budowli - razem mogą zachęcać lub zniechęcać;

4. komponent naukowo-kulturalny - zakłada kreowanie wizerunku poprzez osiągnięcia naukowe, eksponowanie największych dokonań, zatrudnienia wybitnych specjalistów oraz popularyzowanie uczelni przez elementy stroju, konferencje itd.;

5. komponent ekonomiczny - rzeczywista pozycja absolwentów danego kierunku na rynku pracy (Dworak, 2011).

Dowiedziono, że korzystny wizerunek (zwłaszcza w oczach pracodawcy) ma uczelnia, wobec której pracodawca jest w stanie szybko powiązać absolwenta - kandydata do pracy z zestawem konkretnych kompetencji (Solem i in., 2013). Opinia publiczna i pracodawcy nierzadko postrzegają absolwentów wielu kierunków jako grupę o niesprecyzowanym lub bardzo wąskim profilu zawodowym. Dążenie do rozszerzenia i wzmocnienia wyrazistości profilu zawodowego w opisie sylwetki absolwenta i realnych rozwiązaniach programowych wydaje się zasadniczym działaniem prowadzącym do budowania dobrej marki absolwenta (a zatem i kierunku studiów) na rynku pracy (Arrowsmith i in., 2011).

W budowaniu wysokiego prestiżu uczelni duże znaczenie ma realizacja szerokiej palety kursów, zwłaszcza specjalizacyjnych, przez nauczycieli akademickich posiadających praktyczne doświadczenie w danym zakresie. Kapitał naukowej wiedzy, zawodowego doświadczenia i empirycznej znajomości branż, w których absolwenci mogą podejmować pracę związaną z ukończonym kierunkiem studiów, jest jednym z najważniejszych zasobów uczelni. Pożądane jest zatem wyróżnianie takich nauczycieli akademickich i docenianie ich kompetencji w rzeczywistości pracy naukowo-dydaktycznej (Kowalska, 2011).

\section{ZAKOŃCZENIE}

Sytuacja demograficzna Polski, a w konsekwencji malejący popyt na usługi edukacyjne na poziomie wyższym, powoduje, że zarówno uczelnie o mniejszym prestiżu i krótszych doświadczeniach akademickich, jak i renomowane uniwersytety z tradycjami będą musiały zatroszczyć się o własną pozycję, a niekiedy wręcz o dalszą egzystencję na rynku usług 
edukacyjnych. Szkoły wyższe, chcące zachować ciągłość rekrutacji najlepszej populacji młodzieży, muszą być miejscami, w których absolwenci są dobrze przygotowywani do skutecznego konkurowania o zatrudnienie w warunkach permanentnych zmian organizacyjnych i technologicznych. Uczelnie, które nie będą potrafiły wykształcić takich absolwentów, którzy płynnie wejdą na rynek pracy, mogą stracić studentów (Leja, 2002). Niezadowolenie absolwentów ze swojej sytuacji na rynku pracy, przejawiające się obniżaniem liczby i jakości kandydatów na studia, spowoduje kurczenie się kierunku studiów i może poważnie zaszkodzić poszczególnym dyscyplinom naukowym.

Przeanalizowane w niniejszym artykule strategie konkurowania uczelni wyższych wydają się mieć potencjał aplikacyjny, czyli mogą być zastosowane w budowaniu przez uczelnię stabilnej pozycji na rynku usług edukacyjnych oraz w zwiększaniu efektywności procesu kształcenia w zakresie optymalizacji jego jakości i pozyskiwania pracy przez absolwentów. Zaangażowanie w zapewnienie możliwie płynnej i satysfakcjonującej tranzycji absolwentów jest jednym z ważnych elementów budowania wysokiej jakości kształcenia i podlega ocenie przez organy ją weryfikujące. Należy się spodziewać, że wskaźniki zatrudnialności, podobnie jak stało się to w wielu krajach Europy Zachodniej, będą jedną z miar jakości pracy uczelni, współdecydującą o jej pozycji na rynku usług edukacyjnych. Nie chodzi o kształcenie zgodne z wymaganiami czy potrzebami rynku, bo te ulegają znacznie bardziej dynamicznym przemianom czasowym i przestrzennym, niż możliwe jest wprowadzanie zmian w systemie edukacji. Konieczne jest natomiast zbudowanie trwałego przekonania otoczenia danej uczelni o tym, że studia przez nią oferowane wyposażają absolwentów w wachlarz kompetencji:

- czyniących ich konkurencyjnymi pracownikami,

- ułatwiających im płynne wejście w świat pracy jeszcze w toku kształcenia poprzez rozległe i profesjonalne kontakty z pracodawcami,

- zapowiadających relatywnie wysoką pozycję społeczną,

- sprzyjających podnoszeniu jakości życia w regionie.

Do realizacji tego celu służy wypromowany korzystny wizerunek danej szkoły wyższej i zajmowanie przez jej dotychczasowych absolwentów konkurencyjnej pozycji na rynku pracy. Wówczas, jak wskazują wyniki badań, zainteresowanie kandydatów studiowaniem na danym kierunku stabilizuje się na względnie zadowalającym poziomie (Cranmer, 2006; Nunez, Livanos, 2010).

W działaniach podejmowanych, aby zwiększać konkurencyjność uczelni, należy pamiętać, że jedną z podstawowych cech usługi edukacyjnej, wyróżniającą ją wśród innych usług, jest jej długotrwałość. Stąd każde posunięcie powinno być planowane oraz realizowane w perspektywie kilkunastu a nawet kilkudziesięciu lat. Im bardziej przemyślane, trafne i ambitne strategie zostaną zastosowane, tym większa szansa na utrzymanie zainteresowania kształceniem, pomyślność tranzycji absolwenckich i na zbudowane silnej, konkurencyjnej pozycji danej szkoły wyższej na rynku. 


\section{Literatura \\ References}

Arrowsmith, C., Bagoly-Simó, P., Finchum, A., Oda, K., Pawson, E. (2011). Student Employability and its Implications for Geography Curricula and Learning Practices. Journal of Geography in Higher Education, 35(3), 365-377. Doi:10.1080/03098265.2011.563379

Banaszak, B. (2012). Zatrudnialność absolwentów w procesie bolońskim. Forum Akademickie, 9.

Bielecki, P. (2011). Kompetencje absolwentów studiów wyższych w świetle ogólnoeuropejskich badań CHEERS, REFLEX i TUNNG. W: K. Jędralska, K. Bernais (red.). Kompetencje absolwentów studiów ekonomicznych. Perspektywa nauki i biznesu. Katowice: Wydawnictwo Uniwersytetu Ekonomicznego w Katowicach, 13-66.

Cichoń, S. (2010). Nauczanie w szkole wyższej i jego jakość. Problemy Jakości, 42(2), 33-37.

Clark, D., Healey, M., Kennedy, R. (1990). Careers for geographers: the employment experiences of Coventry polytechnic sandwich degree students. Journal of Geography in Higher Education, 14(2), 137-149. Doi:10.1080/03098269008709109

Cranmer, S. (2006). Enhancing graduate employability: best intentions and mixed outcomes. Studies in Higher Education, 3 (2), 169-184. Doi:10.1080/03075070600572041

Doroszewicz, S. (2011). Metodyka i badanie jakości ksztatcenia w szkolnictwie wyższym w Polsce. Warszawa: Oficyna Wydawnicza SGH.

Doucouliagos, Ch., Abbott, M. (2007). Competition and Efficiency: Overseas students and technical efficiency in Australian and New Zealand universities. School Working Paper-Economic Series, Faculty of Business and Law, 9, 1-36.

Douglas, J., Douglas, A., Barnes, B. (2006). Measuring students satisfaction at a UK University. Quality Assurance in Education, 14(3), 251-267. Doi: 10.1108/09684880610678568

Drapińska, A. (2011). Zarządzanie relacjami na rynku usług edukacyjnych szkół wyższych. Warszawa: PWN.

Dworak, J. (2011). Wizerunek szkoły wyższej. Zarzadzanie szkoła wyższq̨. Dylematy $i$ wyzwania. Gdańsk: Zeszyty Naukowe WSB, 14, 107-119.

Franck, E.P., Schönfelder, B. (2000). On the role of competition in higher education - uses and buses of the economic metaphor. Schmalenbach Business Review, 52, 214-237

Fulton, O. (1984). Needs, expectations and responses: new pressures on higher education. Higher Education, 13(2), 193-223.

Hemsley-Brown, J.V., Oplatka, I. (2006). Universities in a competitive global marketplace: a systematic review of the literature on higher education marketing. International Journal of Public Sector Management, 19(4), 316-338. Doi: 10.1108/09513550610669176

Hennemann, S., Liefner, I. (2010). German university education in geography and development: the mismatch between knowledge and competencies required. Journal of Geography in Higher Education, 34(2), 215-230. Doi:10.1080/03098260903227400

Ivy, J. (2008). A new tertiary education marketing mix: the 7ps for MBA marketing. International Journal of Educational Management, 22(4), 288-299. Doi:10.1108/095135408108756

Jakubowska, A., Rosa, A. (2011). Problemy dopasowania oferty kształcenia szkół wyższych do potrzeb rynku pracy w Polsce. Zarządzanie szkoła wyższą. Dylematy $i$ wyzwania. Gdańsk: Zeszyty Naukowe WSB, 14, 29-43.

Kabaj, M., Jeruszka, U. (2009). Lepsze przygotowanie absolwentów szkół wyższych do potrzeb gospodarki i funkcjonowania na rynku pracy. Warszawa: IPiSS.

Kowalska, I. (2011). Doświadczenie praktyczne nauczycieli akademickich - wyznacznik wizerunku szkoły wyższej. W: J. Dworak, J. Jaworski (red.). Zarządzanie szkoła wyższa. Dylematy i wyzwania. Gdańsk: Zeszyty Naukowe WSB, 14, 121-137.

Kryńska, E. (2011). Absolwenci szkół wyższych na rynku pracy. Oczekiwania i rzeczywistość. W: K. Jędralska, J. Bernais (red.). Kompetencje absolwentów studiów ekonomicznych. Perspektywa biznesu i nauki. Katowice: Prace Naukowe UE, 87-101. 
Leja, K. (2002). Uniwersytet - świątynia wiedzy czy sprawnie działająca organizacja. Nauka i Szkolnictwo Wyższe, 1(19), 101-110.

Leja, K. (2013). Doskonalenie relacji z interesariuszami jako wyraz społecznej odpowiedzialności uczelni. W: J. Woźnicki (red.). Misja i stużebność uniwersytetu w XXI wieku. Warszawa: Instytut Społeczeństwa Wiedzy Fundacji Rektorów Polskich, 303-311.

Marginson, S. (2004). Competition and markets in higher education: a "glonocal" analysis. Policy Futures in Education, 2(2), 175-244. Doi.org/10.2304/pfie.2004.2.2.2

Marginson, S. (2006). Dynamics of national and global competition in higher education. Higher Education, 52, 1-39. Doi: 10.1007/s10734-004-7649-x

Nunez, I., Livanos, I. (2010). Higher education and unemployment in Europe: an analysis of the academic subject and national effects. Higher Education, 59(4), 475-487. Doi: 10.1007/s10734-0099260-2

Pawson, E., Fournier, E., Haigh, M., Muniz, O., Trafford, J., Vajoczki, S. (2006). Problem-based Learning in Geography: towards critical assessment of its purposes, benefits and risks. Journal of Geography in Higher Education, 30(1), 103-116. Doi:10.1080/03098260500499709

Piróg, D. (2011). Usługi edukacyjne na poziomie akademickim w kontekście wymagań rynku pracy. Przemiany struktur lokalnych i regionalnych sektora ustug $w$ latach kryzysu gospodarczego. Prace Komisji Geografii Przemystu Polskiego Towarzystwa Geograficznego, 18, 23-36.

Piróg, D. (2012a). Changes to the conception of geography curricula within university education in Poland in the 21 st century in the face of labour market challenges. European Journal of Geography, 3(2), 24-41.

Piróg, D. (2012b). Methods for efficiency improvement of geographical studies within the scope of procurement of work by graduates exemplified by solutions applied in Great Britain and in Germany. W: B. Wójtowicz (red.). Natural sciences in educational systems of European countries in the 21 st century. Kraków: Wydawnictwo Dehon, 129-141.

Romero, L., del Rey, E. (2004). Competition Between Public And Private Universities: Quality, Prices And Exams. Economics Working Papers, Universidad Carlos III, Departamento de Economía.

Schüller, D., Rašticová, M. (2011). Marketing communications mix of universities - communication with students in an increasing competitive university environment. Journal of Competitiveness, $3,58-71$.

Siwiński, W. (2013). Nowa misja uniwersytetów: zdolność konkurowania. W: J. Woźnicki (red.). Misja i stużebność uniwersytetu $w$ XXI wieku. Warszawa: Instytut Społeczeństwa Wiedzy Fundacji Rektorów Polskich, 127-132.

Solem, M., Kollasch, A., Lee, J. (2013). Career goals, pathways and competencies of geography graduate students in the USA. Journal of Geography in Higher Education 37(1), 92-116. Doi:10.108 0/03098265.2012.729563

Sztanderska, U., Minkiewicz, B., Bąba, M. (2005a). Absolwent na rynku pracy. Forum Akademickie, 6.

Sztanderska, U., Minkiewicz, B., Bąba, M. (2005b). Absolwent na rynku pracy, cz II. Forum Akademickie, 7-8.

Teichler, U. (2011). Bologna - Motor or Stumbling Block for the Mobility and Employability of Graduates? Employability and mobility of Bachelor Graduates in Europe. Key results of the Bologna process, Rotterdam/Boston/Taipei: Sense Publishers, 1-2, 3-41.

Ustawa z dnia 27 lipca 2005 r. - Prawo o szkolnictwie wyższym.

Danuta Piróg, dr, Uniwersytet Pedagogiczny w Krakowie, Instytut Geografii.

Jest adiunktem w Instytucie Geografii Uniwersytetu Pedagogicznego w Krakowie. Jej zainteresowania naukowe dotyczą zróżnicowania kulturowego Europy i tożsamości jej mieszkańców, przygotowania kandydatów na nauczycieli geografii i przyrody do przyszłej pracy zawodowej oraz efektywności studiów geograficznych w aspekcie potrzeb rynku pracy. Swoje doświadczenie naukowe pogłębiała poprzez czynny udział w krajowych i międzynarodowych projektach badawczych lub kierowanie nimi. 
Aktualnie zajmuje się przede wszystkim wielowymiarowymi analizami czynników warunkujących procesy tranzycji absolwentów szkół wyższych na rynek pracy.

Danuta Piróg, Ph.D. is an assistant professor at the Pedagogical University of Cracow (Institute of Geography). Her research interests focus on intercultural education; European education; practical preparation of students (candidates for geography teachers); and the effectiveness of geographical studies in the context of the needs of the labour market.

She has been a member of various academic projects on national and European level. Currently her academic activity is centred around multidimensional analysis of determinants of university graduates' transition into the labour market.

\section{Adres/address:}

Uniwersytet Pedagogiczny w Krakowie

Instytut Geografii

ul. Podchorążych 2, 30-084 Kraków, Polska

e-mail: dbutryn@up.krakow.pl 